\title{
Procedimento Público, Religião e Esfera Pública em DEBAte ${ }^{1}$ PUBLIC PROCEDURE, RELIGION AND PUBLIC SPHERE UNDER DEBATE
}

\author{
DOUGLAS FERREIRA BARROS $\left(^{(*)}\right.$ \\ DiEgo INÁCIO FERNANDES VASCONCELLOS ${ }^{(* *)}$
}

\begin{abstract}
RESUMO
$\mathrm{O}$ artigo busca apresentar alguns limites do procedimento público de grupos religiosos, segundo avaliação de Jurgen Habermas. Parte-se da constatação de que visões de mundo calcadas na fé impõem, ou têm imposto, uma série de dificuldades para o estabelecimento de uma ordem plural e democrática em sociedades seculares contemporâneas. Pretende-se, em termos metodológicos, concentrar na discussão de trabalhos mais recentes da obra habermasiana (2006, 2007, 2010, 2012), avaliando e esclarecendo conceitos imprescindíveis de sua reflexão sobre o lugar da religião na esfera pública. No intento de esclarecer os limites dos procedimentos religiosos em sociedades democráticas pretende-se destacar, como conclusão, a insuficiência do princípio do Estado neutro defendido por Habermas.
\end{abstract}

Palavras-Chave: Religião. Esfera pública. Discurso religioso. Político.

\begin{abstract}
The article intends to present some limits of the public procedure of religious groups, according to Jurgen Habermas' evaluation. It begins with the perception that worldviews based on faith impose, or have imposed, a series of difficulties for the establishment of a plural and democratic order in contemporary secular societies. In methodological terms, the intention is to focus on the discussion of more recent works of the Habermasian writings (2006, 2007, 201O, 2012), evaluating and discussing essential concepts of its reflection on the place of religion in the public sphere. In attempt to clarify the limits of religious procedures in democratic societies, it is necessary to emphasize, as a conclusion, the insufficiency of the neutral state principle defended by Habermas.
\end{abstract}

KEYWORDS: Religion. Public sphere. Religious discourse. Political.

\section{INTRODUÇÃO}

\footnotetext{
$1 \mathrm{O}$ trabalho foi executado a 4 mãos e é parte de discussões e discordâncias entre os autores acerca do tema do lugar do discurso religioso em contextos públicos contemporâneos. Contém argumentos em defesa da proposta habermasiana, que contemplam a pesquisa de Diego Inácio, e argumentos que tentam aprofundar os limites dessa perspectiva, que contemplam parte da pesquisa de Douglas F. Barros, desde 2014. Partes do artigo foram debatidas na ocasião da $29^{\mathrm{a}}$. Reunião Anual da Soter, em Belo Horizonte, dias 1214/07/2016. Por isso, agradecemos os colegas do Fórum Temático 04: Espaço religioso entre o público e privado, pelas observações e questionamentos. Outras partes do argumento sobre os limites da religião na esfera pública foram debatidas em: VASCONCELLOS, Diego I. F. Critérios de inserção do discurso religioso na esfera pública no contexto das democracias pós-seculares, segundo Jürgen Habermas. Campinas, 2017. 101 f. Dissertação (Mestrado em Ciências da Religião) Programa de PósGraduação em Ciências da Religião da PUC-Campinas.

(*) Professor de Filosofia na PUC-Campinas. Doutor e Pós-doc em Filosofia pela Universidade de São Paulo, iniciou os estudos sobre a relação entre política e religião em seu período de doutorado sanduíche na EHESS - Paris. Tem se dedicado à pesquisa, entre outros temas, da relação entre soberania e a TeologiaPolítica na modernidade e na contemporaneidade. Vinculado ao PPG em Ciências da Religião da mesma Universidade. Autor de, entre outros, Julgar a República: método, soberania e crítica à liberdade no Methodus de Jean Bodin. São Paulo: Loyola/FAPESP/Discurso, 2012. Lattes: id=K4736867U1. E-mail: douglasfbarros@gmail.com.

${ }^{(* *)}$ Mestre em Ciências da Religião pela PUC-Campinas. Professor de filosofia para os níveis fundamental e médio da rede pública em Campinas. E-mail: diegofilaleto@gmail.com
} 


\section{PROCEDIMENTO RELIGIOSO PÚBLICO COMO PROBLEMA}

A consistência na abordagem de problemas contemporâneos é um entre os vários índices que confirmam a importância de Habermas no contexto das filosofias que se destacaram desde a segunda metade do século XX. Das diversas dimensões de sua avaliação sobre a esfera pública, um aspecto tem ganhado especial destaque: a investigação sobre o lugar da religião, dos religiosos e dos perigos e desafios que ambos comportam. Não se trata de tema ocasional ou temporão em sua obra. Confirma Araújo (1996, p.15) que a religião é tema privilegiado na obra habermasiana desde o debate sobre a modernidade (2000) e a esfera pública (2014). Em suas primeiras obras, o tema é abordado sob a ótica da legitimação social, mas tem adquirido novas interpretações desde as mais recentes intervenções a respeito dos limites da ciência (2007) e da fé (2006; 2007; 2012).

Sobretudo após os eventos do 11 de setembro de 2001, quando "a tensão entre a sociedade e a religião explodiu de um modo inteiramente diverso" (2012, p. 2), Habermas põe ênfase na defesa de limites ao procedimento religioso na esfera pública. Por procedimento religioso público entende-se o conjunto de práticas, valores, princípios e costumes que, cultivados por membros de uma denominação religiosa específica, ultrapassam os limites compartilhados na esfera íntima e privada e interferem no domínio público, seja para se afirmar em relação a outros procedimentos públicos religiosos ou não religiosos, seja para se apresentar como portador de verdades que, por si mesmas, devem se impor em relação às instituições sociais, políticas e religiosas bem como às visões de mundo que lhe são distintas. No caso dos religiosos que, motivados por convicções fundamentalistas, agiram nos atentados de 2001 e têm atacado desde então mundo afora com grande apelo midiático, Habermas faz questão de destacar que os marcos da modernidade iluminista - tão enfaticamente defendidos em várias de suas obras $(2000 ; 2014)$ - constituem para eles o grande Satã (2012, p. 03).

O objetivo do presente artigo é aprofundar, nas mais recentes obras de Habermas, os limites estabelecidos pelo filósofo acerca desse procedimento público religioso. Como defensor do liberalismo político de matriz iluminista, ele defende a necessidade de que as instituições sociais e políticas estejam ordenadas por princípios pós-seculares, isto é, distantes e, tanto quanto possível, imunes à influência religiosa ou do que ele chama de visões de mundo abrangentes. Suas críticas apontam para a necessidade de que as instituições sociais e políticas em uma sociedade plural, constituída por cidadãos com distintas e conflitantes vi- 
sões de mundo, façam valer os ideais da secularização, segundo os quais "modos de pensar e formas de vida religiosas são substituídos por equivalentes racionais" (2012, p. 5). Para que uma sociedade assim se ordene, é preciso que o procedimento religioso público se apresente restrito a limites racionalmente defensáveis. Que procedimentos seriam esses? Que limites seriam os mais razoáveis em um contexto de sociedade plural e multi-religiosa?

\section{SOCIEDADES PÓS-SECULARES E ASPECTOS DO LIBERALISMO HABERMASIANO}

A defesa de uma “..sociedade pós-secular”2 envolve, para Habermas, a tese de que instituições sociais e políticas em uma sociedade determinada estejam em processo de ajuste ou plenamente ajustadas "...à sobrevivência de comunidades religiosas em um ambiente cada vez mais secularizante" (2012, p.06). Isto que dizer -diferentemente do que defendem os mais renitentes defensores da secularização a todo custo- que a sociedade pós-secular comporta a permanência e partilha da mesma esfera pública de grupos religiosos distintos, assim como indivíduos que não partilham qualquer identidade religiosa e aqueles manifestamente não religiosos.

Habermas entende que a neutralidade do Estado se exprime no distanciamento das instituições sociais e políticas as mais diversas, em relação às diferentes visões de mundo. Por neutralidade devemos entender que tais estruturas de poder e de ordenamento social não têm "qualquer predisposição a tomar decisões políticas em favor desta ou daquela parte” (2012, p.o8). O ambiente secularizante, nesse caso, exige que os diferentes ajustem as suas visões particulares de mundo a uma dinâmica plural na relação que mantêm publicamente. Em textos recentes, Habermas afirma que o Estado atua forçando o estabelecimento desta convivência plural, que pode em certos momentos até ser conflitiva.

A razão pluralizada do público constituído pelos cidadãos do Estado só segue uma dinâmica de secularização na medida em que força, no resultado, a um distanciamento igual em relação às tradições fortes e aos conteúdos impregnados de visões de mundo. Sem renunciar à sua autonomia, ela permanece contudo aberta, como que osmoticamente, para a possibilidade de aprender com ambas as partes do conflito (2012, p.8).

\footnotetext{
${ }^{2}$ Não é o caso, neste texto, de se retomar a discussão sobre a virada do paradigma da consciência para o da filosofia da linguagem - que está na matriz da formulação de um pensamento pós-metafísico, do qual Habermas é herdeiro e formulador, e com base no qual ele estabelece a sua reflexão acerca da religião, da secularização e do estabelecimento de critérios racionais de convivência entre os diferentes tipos de visão de mundo na esfera pública. Conforme HABERMAS, J. Pensamento pós-metafísico. Rio de Janeiro: Tempo Universitário, 2002.
} 
Esse ajuste secularizante pressupõe, segundo a defesa de Habermas, instituições sociais e políticas ordenadas por um Estado liberal. Por seu lado, os religiosos são reconhecidos como razoáveis na esfera pública quando suas comunidades "renunciam à imposição violenta de suas verdades de fé, à pressão militante sobre as consequências de seus próprios membros, e tanto mais à manipulação para atentados suicidas" (p.o6). O filósofo vê como imprescindível que o Estado não ceda à tentação de pender para qualquer dos lados entre diferentes grupos, ainda que esteja premido pelas tradições culturais e religiosas que também, de certo modo, o constituíram. Se aos religiosos cabe forçar o ajuste secularizante, do Estado espera-se que se oriente para preservar o ambiente pluralista. 3 Por um lado, o ajuste obriga os religiosos e os não religiosos a se conformarem ao fato de que sua visão de mundo é uma entre outras; por outro, o Estado mesmo deve estar ajustado ao pluralismo. Habermas concebe o senso comum democraticamente esclarecido, isto é, "algo que descreve a constituição mental de uma esfera pública com muitas vozes" (2012, p.16). Como pensar que o Estado possa se abrir a tal perspectiva?

Em Dialética da secularização (2007), Habermas defende o liberalismo político como uma "justificativa não religiosa e pós-metafísica dos fundamentos normativos do estado constitucional moderno" (HABERMAS, 2007, p. 27). Tal premissa se enquadra na tradição de um direito racional que dispensa presunções fortes de ordem cosmológica, ou da história da salvação, com base nas doutrinas clássicas e religiosas do direito natural. Habermas defende que não é recente o afastamento do discurso público e secular de quaisquer tipos de pretenções de embasamento religiosos, característica que é enaltecida inclusive por religiosos que compartilham o senso comum democraticamente esclarecido.

Em detrimento da convivência pacífica entre grupos distintos, não é difícil encontrar movimentos políticos, desde o século XX, que procuram enaltecer a superioridade de uma orientação religiosa em face de outras, religiosas ou não. Certo da incapacidade que estados e grupos políticos possam estabelecer uma justificação racional dessa suposta supremacia, Habermas é enfático: "não há lei (Direito) ou política que valide e delimite o alcance dos discursos. O Estado não tem competência para dizer quais os limites de um discurso ou outro" (HABERMAS, 2006, p. 127). As bases legitimadoras de um poder ideologicamente neu-

3 Diz Habermas que em uma sociedade pluralista: “[...] a consciência religiosa tem de assimilar o encontro cognitivamente dissonante com outras confissões e religiões; [...] ela tem de adaptar-se à autoridade das ciências, que detêm o monopólio social do saber mundano [...]. Tem de adequar-se às premissas do Estado constitucional, que se fundam em uma moral profana” (2012, p. 07). 
tro, segundo Habermas, provêm das fontes profanas da filosofia dos séculos XVII e XVIII, especificamente o pensamento iluminista4.

A expectativa normativa que se impõe perante as comunidades religiosas que integram o Estado liberal poderá fazer com que estas confundam seus próprios interesses, uma vez que existe a possibilidade de que exerçam, por meio da esfera pública política, sua própria influência sobre a sociedade como um todo (HABERMAS, 2007). Habermas aborda a questão da fundamentação liberal do Estado sob alguns aspectos: o primeiro diz respeito à admissão de uma justificativa secular, não religiosa e pós-metafísica, uma vez que o direito tenha se tornado totalmente positivo; o segundo, diz respeito à dependência que a ordem liberal faz da solidariedade, de seus cidadãos e da possível exaustão das fontes profanas e o risco de que traria um descarrilhamento do processo de secularização. Desde a perspectiva cognitiva, Habermas propõe “que a secularização cultural seja entendida como um processo de aprendizagem dupla que obriga tanto as tradições do Iluminismo quanto as doutrinas religiosas a refletirem sobre seus respectivos limites" (HABERMAS 2007, p. 25).

Quanto às sociedades pós-seculares, o filósofo levanta a seguinte questão: "quais orientações cognitivas e expectativas normativas o Estado liberal precisa exigir dos seus cidadãos crentes e não crentes no relacionamento mútuo?” (HABERMAS 2007, p. 26). A carga pela consequência das escolhas não será distribuída simetricamente sobre os crentes e não crentes, conforme mostram as normas mais ou menos liberais para a prática do aborto, mas a consciência secular também tem que pagar seu tributo para gozar da liberdade religiosa negativa. "Espera-se dela [da consciência secular] o exercício no relacionamento auto-reflexivo com os limites do Iluminismo" (HABERMAS, 2007, p. 55). A concepção de tolerância nas sociedades pluralistas de constituição liberal exigirá dos crentes que entendam, em suas relações com os descrentes e com os membros de outras religiões, que precisam contar sensatamente com a continuidade de um dissenso. Dos descrentes, por sua vez, numa cultura política liberal exigese a mesma compreensão no relacionamento com os religiosos, pois é do interesse comum a persistência de visões diferentes: "Para o cidadão sem tino para a religião, isso significa que ele recebe uma convocação nada trivial para deter-

\footnotetext{
4 Diz Habermas: "Kant não quiz que o dever categorial desaparecesse na esteira do auto-interesse esclarecido. Ele ampliou o livre-arbítrio para a autonomia e, por conseguinte, deu o primeiro grande exemplo de uma desconstrução secularizadora, porém, ao mesmo tempo, redentora, das verdades de fé. Em Kant, a autoridade dos mandamentos divinos encontra validade incondicional das obrigações morais um eco impossível de não ser ouvido. Com seu conceito de autonomia, ele destrói a ideia tradicional de sermos todos filhos de Deus" (2010, p. 147).
} 
minar de maneira autocrítica a relação entre fé e conhecimento na base do conhecimento geral do mundo" (HABERMAS, 2007, p. 56).

Habermas sustenta que bastam razões fracas para defender um conceito não derrotista da razão que seja capaz de garantir a constituição comunicativa das formas de vida socioculturais no contexto contemporâneo. Para o filósofo, uma tarefa importante seria explicar, primeiro, por que o processo democrático é aceito como um processo legítimo de criação de direitos; e, segundo, por que a democracia e os direitos humanos estão interligados com a mesma primordialidade no processo constituinte (HABERMAS, 2007). Essas questões orientam a investigação no sentido de responder em que medida a liberdade religiosa deve ser entendida, sobretudo, como uma espécie de garantia que está intimamente vinculada aos direitos humanos e à dignidade da pessoa humana, não sendo mero capricho ou souvenir das modernas democracias. O fato de as democracias liberais garantirem, por meio da constituição democrática dos seus direitos, o direito de liberdade de consciência e crença, é um indicador a ser considerado. Em sentido contrário, seria possível suspeitar na medida em que pareça correto falar em liberdade de consciência e crença em países cuja constituição vinculase a um texto sagrado de uma religião específica que, estabelecida em seu respectivo código de conduta moral, outorgado por intermédio de um líder ou comunidade religiosa, é capaz de perpetuar-se pela força de uma ideologia dominadora. "O processo democrático satisfaz as condições de uma formação inclusiva e discursiva da opinião e da vontade, e assim justifica a presunção de aceitabilidade racional dos resultados" (HABERMAS, 2007, p. 29). Ademais, "a institucionalização jurídica do processo de criação democrática do direito exigirá a garantia simultânea, tanto dos direitos básicos liberais quanto dos políticos” (HABERMAS, 2007, p. 30).

Nesse sentido é possível afirmar que o Estado secular democrático e liberal é uma das condições para a participação dos discursos religiosos na esfera pública, uma vez que a fundamentação dessa esfera perpassa a criação de direitos e a constituição que os cidadãos associados se dão a si mesmos, "não a domesticação de um poder de Estado pré-existente" (HABERMAS, 2007, p. 30). Não se exclui que o discurso religioso possa dirigir-se criticamente à ordem democrática, uma vez que o limite da razoabilidade bastaria para adequar às formalidades de uma linguagem pública as pretenções de determinada comunidade tradicional. Espera-se que os cidadãos religiosos exerçam ativamente seus direitos de comunicação e participação, tanto segundo um interesse próprio legítimo, quanto em vista de um bem comum. Para Habermas (2007) isso exige um mai- 
or esforço e motivação, uma vez que não pode ser obtido dentro do âmbito legal por meio da coação.

Assim, uma condição de participação dos discursos de fundamentação religiosa na esfera pública é a liberdade religiosa garantida pelo próprio Estado comprometido com a constituição democrática, liberal e secular de direitos. Uma ordem liberal pode ser o suficiente para manutenção de uma atmosfera religiosamente estável; mas não será o bastante para estabelecer como deverão se relacionar religiosos e não religiosos do ponto de vista da discussão das questões públicas. Uma vez que a ordem democrática procura afirmar os direitos fundamentais por meio de leis estabelecidas segundo o interesse de uma sociedade, não bastariam as leis para justificar o espaço de democracia da esfera pública, inclusive do ponto de vista religioso. A própria sociedade deverá comprometerse com uma moralidade pública, o laço indissociável entre a elaboração das leis e sua consolidação por meio da adesão da sociedade (HABERMAS, 2007).

Nessa acepção, o termo político é compreendido em sentido fraco, e Habermas o entende como o lugar onde se expressam as mais diversas formas da cidadania. A condição de cidadão é garantida desde a perspectiva do indivíduo possuidor de direitos, cuja tutela é distribuída pelos poderes do Estado democrático de direito - o contexto do político. Aqueles que discursam em nome de uma tradição ou valor religioso devem compreender-se coautores daqueles mesmos direitos que valorizam a existência das diversas posições políticas, filosóficas, ideológicas e religiosas.

En resumen, la formación de la opinión y la voluntad en el espacio público democrático sólo puede funcionar si un número suficientemente grande de ciudadanos cumple determinadas expectativas relativas a un comportamiento cívico que allane también ciertas diferencias profundas tocantes a las creencias religiosas y a las visiones de mundo. (HABERMAS, 2006, p. 12).

Duas características principais derivam da garantia oferecida pelo Estado liberal no tocante aos discursos religiosos. Pelo fato de o Estado ter assumido uma posição neutra em relação às diversas formas de expressão religiosa (HABERMAS, 2007), isto o impede, em tese, de estabelecer uma limitação formal em relação a qualquer discurso religioso, quando se trata da esfera pública. Isso se dá à medida que o estamento burocrático, oriundo da racionalização própria das formas de vida modernas, personificado na figura do Estado liberal, recai no âmbito da esfera do sistema geral das práticas e dinâmicas institucionais. A esfera discursiva, ao contrário, se caracterizada pela interação no mundo da vida, sendo ela uma atmosfera própria à razão discursiva, ou seja, cumpre à esfera pública politicamente ativa pressionar a esfera do sistema segundo seus interes- 
ses consensuais (HABERMAS, 2007). Caberá aos discursos religiosos, uma vez que não possam ser limitados (salvo quando prejudicarem direitos e se colocarem como parâmetro de verdade fundando ações de dominação e controle sobre os que se encontram fora desse universo discursivo e de fé), que estes não arroguem para si o caráter de absolutos, posto que a esfera pública não é compatível com uma visão de mundo única e exclusiva acerca da totalidade da vida, nem mesmo uma visão de mundo de matriz secular: "A neutralidade ideológica do poder do Estado que garante as mesmas liberdades éticas a todos os cidadãos é incompatível com a generalização política de mundo secularizado" (HABERMAS, 2007, p. 57). Ao contrário, a característica principal da esfera da interação consiste em prescindir de fundamentações últimas para alcançar resoluções validadas democraticamente no processo decisório.

Como então poderá uma denominação religiosa proceder no Estado? Como partícipe da construção, elaboração e da legitimação do arcabouço jurídico e institucional, quais os limites de sua tática e discurso religiosos? Se for atendida a condição propiciada de liberdade religiosa, legitimada pelo processo decisório democrático, poder-se-á, então, considerar alguns dos pressupostos cardeais da ética do discurso e da teoria do agir comunicativo, sendo que, para Habermas (2012), há ao menos quatro pretensões de validade igualmente originárias, próprias no agir comunicativo: inteligibilidade, verdade, correção e sinceridade. Essas pretensões de validade compõem um aspecto importante do horizonte de prática discursiva e de procedimento público a que Habermas designará por conduta racional em uma sociedade democrática secular.

\section{INTELIGIBILIDADE, VERDADE E RENÚNCIA AO ABSOLUTO NA ESFERA PÚBLICA}

A primeira pretensão de validade de uma razão comunicativa corresponde à inteligibilidade e pode ser considerada não apenas um critério, mas uma exigência ou condição da própria comunicabilidade. Os homens, entretanto, formam comunidade porque se comunicam, participando reciprocamente dos seus modos de ser, que adquirem novos e imprevisíveis contornos. Portanto, justifica-se a importância dada por Habermas à tarefa de superar um paradigma do sujeito, caracteristicamente monológico, por um paradigma da intersubjetividade. Para Habermas (2010), a força da razão comunicativa se justifica dentro de um contexto pós-metafísico e satisfaz as condições de uma esfera pública politicamente ativa. Com a modernidade, o ethos religioso se decompõe como referência de legitimação no âmbito público e político. Se muitas das posições politicamente sustentadas partem de uma posição confessional, isso se dá pelo fato 
de estarem atendidas certas condições universais nos discursos religiosos, que se tornaram presentes na expressão da normatividade do Estado quando submetidas à legalidade do direito e que "conseguem manter um lugar em meio a estrutura diferenciada da modernidade porque o seu conteúdo cognitivo ainda não perdeu a validade" (HABERMAS, 2007, p. 161-2).

A inteligibilidade enquanto critério de validação dos discursos, tanto religiosos quanto seculares, caminha no sentido de reafirmar a intersubjetividade, em sentido contrário à perspectiva da dominação. A posição de Habermas, quando pressupõe o uso público da razão, condiz com uma mudança de mentalidade que procura explicitar os conteúdos morais provenientes da religião para uma linguagem acessível a uma maior quantidade de pessoas. Impõe-se, portanto, a necessidade de uma mudança epistêmica que resulte numa certificação autocrítica dos limites da razão secular e da religião em sociedades pluralistas (ARAÚJO, 2015). Segundo Habermas: "Tal pressuposição significa que o ethos democrático de cidadãos do Estado [...] só pode ser imputado simetricamente a todos os cidadãos se estes, tanto seculares como religiosos, passarem por processos de aprendizagem complementares (HABERMAS, 2007, p. 158).

A livre discussão, por meio da qual é possível chegar ao entendimento sobre questões comuns entre os povos e de um povo com ele mesmo, é a própria comunidade ideal, cuja diversidade de posições é a marca característica. O principal problema da racionalidade comunicativa em nossa sociedade, tratado por Habermas na obra Teoria do agir comunicativo (1981), não seria relativo às dificuldades próprias ao processo da autotransparência de um discurso inteligível, mas à difusão sistemática de uma comunicação deformada. O agir comunicativo se pretende um agir com objetivo fundamental do entendimento por meio da linguagem. Difere-se, todavia, do agir estratégico, cuja finalidade é a autoafirmação, o sucesso e o poder; cuja forma de obtenção desses objetivos instrumentaliza a linguagem, causando diversas deformações no processo de compreensão inter-humana. Assim, a compreensão do critério de inteligibilidade é importante, uma vez que revela uma ou várias propriedades intrínsecas à comunicação, como compreendem os filósofos e sociólogos contemporâneos, sem as quais não seria possível o estabelecimento do consenso e o livre convencimento por meio da argumentação racional.

A bem dizer, a inteligibilidade, mais que uma pretensão de validade, deve ser designada como uma exigência ou uma condição de comunicabilidade. Uma vez preenchida esta condição mínima, pode-se falar então de três pretensões de validade, entre as quais somente a "verdade" e "correção" são suscetíveis de ser honradas mediante argumentos, através dos discursos teóricos, no primeiro caso, e 
dos discursos práticos, no segundo. A "sinceridade" ou "veracidade" é, com efeito, uma pretensão não discursiva de validade, pois ela "não se deixa fundamentar, mas apenas mostrar". A não veracidade pode se delatar na falsa coerência entre uma expressão e as ações vinculadas internamente a ela (HABERMAS, 2012b, p. 57).

É possível entender que o tema da religião não pode ser compreendido desde a perspectiva de uma teoria da religião isolada no corpus habermasiano. A rigor, Habermas não possui uma teoria da religião: possui, isto sim, uma teoria do agir comunicativo fundamentalmente composta por outras três teorias não menos importantes: uma teoria da modernidade, uma teoria da racionalidade e por, consequência, uma teoria da sociedade. Dessa forma, é possível afirmar que não há perspectiva religiosa por parte de Habermas para tratar do tema da religião, mas muito mais um ponto de vista multidisciplinar. A filosofia, segundo Habermas (2010), na posição de guardiã do espaço de discussão racional assume o lado secular do conflito entre as mentalidades, mas nem por isso estará menos interessada nos temas da religião. Todavia, para Habermas, a esfera pública prescinde das fundamentações teológicas que, em alguns casos, são ininteligíveis.

A verdade corresponde à pretensão de validade, que é suscetível de ser honrada mediante procedimentos intelectivos, como a argumentação por meio dos discursos teóricos. É o campo dos embates teóricos e da fundamentação intelectual das posições políticas. Desde a perspectiva habermasiana, a verdade tem papel destacado, uma vez que sua dimensão está em disputa, embora a verdade propriamente não ceda perante a necessidade de convencimento. Não se trata de buscar a verdade metafísica, mas de compreender que existem realidades subsistentes que independem das posições filosóficas, políticas ou ideológicas dos indivíduos. A verdade não será revelada senão por meio de um processo interpretativo, sendo, portanto, objeto de consideração dos hermeneutas.

Deve-se considerar o critério da verdade como uma chave valiosa para compreensão da viabilidade de discurso na esfera pública, uma vez que, da esfera pública, não se demanda uma visão cosmológica ou metafísica forte; ao contrário, prefere-se adotar uma postura aberta, uma vez que não decorre da domesticação de um poder pré-existente. Ao adentrar o campo do livre convencimento que constitui a esfera pública, os discursos de orientação religiosa deverão fazêlo não como se falassem para convertidos, para os que compartilham da mesma visão de mundo, mas respeitando a posição daqueles que, eventualmente, ignoram por completo a perspectiva teológica da salvação, por exemplo, ou os dogmas de fé. Uma exigência perante a verdade, segundo Habermas, seria a da au- 
tolimitação em relação à extensão veritativa do que dizem os religiosos. Tal limitação seria interessante que viesse daquele que dirige a fala perante os demais, não os considerando desprivilegiados por não adotarem essa ou aquela confissão religiosa, mas como concidadãos cujas posições, racionalmente estabelecidas devem ser consideradas e respeitadas. A questão da verdade remete ao âmago da controvérsia acerca da dignidade epistemológica dos ensinamentos da fé.

Por outro lado, a consciência religiosa se vê forçada a aceitar alguns processos de adaptação.

Toda religião é originalmente uma visão de mundo, ou uma comprehensive doctrine, inclusive no sentido de reivindicar autoridade de estruturar a forma de vida como um todo. Sob a pressão da secularização do conhecimento, da neutralização do poder do Estado e da liberdade religiosa generalizada, a religião se viu obrigada a desistir da pretensão ao monopólio de interpretação e à forma normativa e abrangente de vida. Com a diferenciação funcional progressiva de sistemas sociais parciais, a vida da comunidade religiosa também se separa de seu entorno social (HABERMAS, 2007, p. 53).

Para Habermas (2007), o papel do membro da comunidade religiosa diferencia-se do papel do cidadão; o Estado depende da integração política dos seus cidadãos, sem que esta integração seja restrita a um modo de vida exclusivo. A diferenciação que há entre religioso e cidadão não pode ser absorvida numa simples adaptação dos modos de pensar e do ethos religioso às leis impostas pela sociedade (HABERMAS, 2007). Seria necessário que a ordem jurídica universalista e a moral igualitária fossem conectadas internamente ao ethos das comunidades e que uma perspectiva decorra consistentemente da outra.

A expectativa de uma não convergência continuada entre fé e conhecimento apenas poderá merecer o atributo de sensata, se for admissível que as convicções religiosas ganhem também, na perspectiva do conhecimento secular-profano, um status epistêmico que não seja pura e simplesmente irracional. É por isso que na esfera pública política as visões naturalistas do mundo - que, baseando-se numa elaboração especulativa de informações científicas, são relevantes para o autoconhecimento ético dos cidadãos - não gozam de prerrogativas em relação às concepções ideológicas ou religiosas concorrentes. (HABERMAS, 2007, p. 56-7).

Nesse sentido, não se pode dizer que a busca da verdade não seguirá os métodos específicos das ciências naturais, uma vez que se procura nela o valor capaz de mediar as discussões com vistas ao consenso. A postura ideal daqueles que interagem na esfera pública, jamais será de procurar fazer valer suas posições por meio da coerção, ainda que baseada em argumentos científicos. Assim, 
não haverá privilégios para aqueles que falam em nome da ciência ou de quaisquer posições ideológicas.

Em seu papel de cidadãos do Estado, os cidadãos secularizados não podem nem contestar em princípio o potencial de verdade das visões religiosas de mundo, nem negar aos concidadãos religiosos o direito de contribuir para os debates públicos servindo-se de uma linguagem religiosa. (HABERMAS, 2007, p. 57).

Uma cultura política liberal, segundo Habermas (2007), pode até esperar que seus cidadãos secularizados participem de esforços em traduzir as contribuições relevantes em linguagem religiosa para uma linguagem que seja acessível publicamente. Isso trará, inevitavelmente, o abandono das pretensões de que visões de mundo absolutizantes prevaleçam frente àquelas sem a mesma pretensão. Aqui nos colocamos diante de uma aporia: se um dos critérios é o de inteligibilidade, e outro é o critério de verdade, sendo a verdade expressa em linguagem religiosa, ainda que não se arrogue de um valor absoluto, não pode ser contestada segundo sua forma, como poderia ser justificada do ponto de vista da inteligibilidade? Nesse ponto, Habermas deixa transparecer o alto grau de idealismo de sua proposta comunicativa, uma vez que pressupõe cidadãos dispostos a participar da tarefa conjunta de tradução cooperativa dos conteúdos religiosos.

Na perspectiva de Habermas (1997), a verdade tem como alcance as questões relacionadas à busca do consenso e, por consequência, o estabelecimento da democracia participativa. Como a verdade se dá por meio da interpretação, é possível encontrar uma espécie de concorrência hermenêutica com fins à coesão social:

É nisso que consiste o agir comunicativo. Neste caso os atores, na qualidade de falantes e ouvintes, tentam negociar interpretações comuns da situação e harmonizar entre si os seus respectivos planos através de processos de entendimento, portanto pelo caminho de uma busca incondicionada de fins ilocucionários (HABERMAS, 1997, p. 36).

A realidade é, por sua vez, expressão da verdade alcançada por meio da interpretação. Fica clara, portanto, a importância do conceito de verdade estabelecer o campo da disputa das interpretações dentro da esfera pública. A verdade, ademais, pode ser disputada mediante argumentação e verificada desde a dimensão teórica. Certamente o religioso que procura a noção de verdade de modo distorcido àquele previsto na ética do discurso, trará suspeita de estar agindo não segundo a esfera da interação, mas segundo a lógica da razão instrumental com vistas à dominação. 
Apesar dos conceitos de consenso e de verdade estarem relacionados à provisoriedade e à relatividade, isso não implica em um impedimento de sua implementação; ao contrário, significa que o intérprete do direito deve estar aberto às mudanças que ocorrem na sociedade, assim como deve estar apto a entender que essa mesma sociedade é um organismo vivo e, como tal, se transmuta, se modifica, se adapta a novas realidades, a novas leituras de mundo. Essa verdade, esse consenso, cujo interesse está voltado à emancipação, está imerso na intersubjetividade de uma compreensão que se dá mutuamente, uma vez que os participantes do agir comunicativo são diferentes, logo, possuem perspectivas de vida e necessidades diferentes.

O saber religioso acerca da dimensão própria ao critério de validação da verdade deverá, segundo a perspectiva habermasiana, administrar a seguinte demanda ou condição para que proceda racionalmente na esfera pública: a fé deve enfrentar a questão do pluralismo. No Estado secular, as visões de mundo amparadas na fé deverão reconhecer a posição privilegiada em que as ciências se encontram para solucionar problemas de ordem coletiva e individual. Como vimos, as condutas desses seguidores da fé deverão pautar-se em acordo com o primado do Estado laico. Nesse sentido, torna-se inviável, do ponto de vista da inserção dos diferentes discursos no contexto de uma esfera pública secular, a sustentação de perspectivas absolutistas, verdades absolutas ou dogmas de fé. $\mathrm{O}$ dogma é um caso particular de princípio de fé vedado ao questionamento. Desrespeitar alguns dos dogmas de fé faz do crente um herege doutrinário, alguém que toma apenas parte dos ensinamentos. Todavia, o imposto a ser pago por todos em nome da esfera pública plural é abrir mão de suas posições de verdade e pretensões absolutizantes quando procedem publicamente como portadores de uma crença de fé ou não, de uma religião ou não. Igualmente, os discursos que se dirigirem desde a perspectiva da verdade absoluta, incontestável, ferem a pretensão que demanda a maior universalidade possível aos discursos públicos, a fim de contemplar o interesse público de modo mais abrangente e plural possível. Habermas entende que submeter os discursos religiosos a uma aceitabilidade universal pode ferir de morte uma participação espontânea, excluindo injustamente várias visões de mundo que satisfazem do ponto de vista da correção, ou seja, satisfazem a condição do mundo social, encontrando eco em outras subjetividades.

A busca por razões que visam à aceitabilidade universal só não faria com que a religião fosse injustamente excluída da esfera pública, e só não privaria a sociedade secular de fontes importantes para a instituição do sentido, se também o lado se- 
cular conservasse para si uma sensibilidade ao poder de articulação das linguagens religiosas. (HABERMAS, 2010, p. 145-6).

A advertência pode ser entendida como um desafio acerca da experiência da esfera pública em sociedades democráticas seculares. É justificável a perspectiva habermasiana de rejeitar as presunções últimas de fundamentação com base no próprio conceito de racionalidade. Assim, o filósofo toma o cuidado de adotar para si não uma teoria da racionalidade característica da modernidade objetivante do sujeito, autônoma, mas no sentido de constituir suas próprias autolimitações como princípio racional em face daqueles que lhe são distintos.

\section{CONSIDERAÇÕES FINAIS}

\section{UM MESMO ESPAÇO PÚBLICO E O POLÍTICO EM SENTIDO FRACO}

Caso se tome a abordagem habermasiana como um conjunto de medidas reguladoras da convivência plural na esfera pública, tem-se que admitir que, por um lado, a consciência religiosa fica obrigada a aceitar alguns processos de adaptação. Pressionada pela secularização do conhecimento, entre outros aspectos, a religião se vê obrigada a renunciar a uma pretensão ao monopólio da interpretação e à forma normativa e abrangente de vida (HABERMAS \& RATZINGER, 2007). Contudo, o Estado liberal concebido pelo filósofo pressupõe a integração dos seus cidadãos, e essa integração não pode se restringir a um modus vivendi exclusivo. Não se trata de uma adaptação cognitiva, dirá Habermas (2007, p. 54), do ethos religioso às leis impostas pela sociedade secular. É necessário que a ordem jurídica conecte-se internamente ao modo de vida das comunidades religiosas, de modo que um elemento decorra de outro consistentemente. A expectativa normativa imposta pelo Estado liberal às comunidades religiosas deve se confundir com os próprios interesses dessas mesmas comunidades (HABERMAS, 2007). Espera-se, igualmente, dos que assim se considerem não religiosos, o exercício autorreflexivo com os limites da tradição Iluminista.

A concepção de tolerância das sociedades pluralistas de constituição liberal não exige apenas dos crentes que entendam, em suas relações com os descrentes e os crentes de outras religiões, que precisam contar sensatamente com a continuidade de um dissenso, pois numa cultura liberal exige-se a mesma compreensão também dos descrentes no relacionamento com os religiosos. (HABERMAS \& RATZINGER, 2007, p. 55).

Sobre as condições a serem cumpridas pelos cidadãos religiosos, cabem destacar as que dizem respeito em sentido amplo à conduta dos indivíduos todos de 
uma sociedade secular. As convicções de fé devem estar em diálogo - "relação reflexiva" - com a multiplicidade de religiões e visões de mundo.

Los ciudadanos religiosos solo pueden afrontar estas expectativas en el supuesto de que cumplan de hecho determinadas condiciones cognoscibles imprescindibles. Deben haber aprendido a poner las convicciones de su propia fe en una relación reflexiva y lúcida con el hecho del pluralismo de religiones y cosmovisiones, $y$ deben haber harmonizado su fe con el privilegio epistemológico de las ciencias socialmente institucionalizadas, con el primado del Estado laico, y con la moral universalista de la sociedad. (HABERMAS, 2006, p. 12).

A compreensão habermasiana do estado laico, um estado neutro em relação aos grupos distintos que compõem a esfera pública, tem pressuposta a ideia de retorno do político. Não é o caso pensar no político, digamos, em sentido forte como em Hobbes: "com um Estado de segurança globalizado, ou seja, com dimensões de polícia, serviço secreto e forças militares" -, mas na formulação de "um poder mundial de configuração civilizadora" (2012, p.04). Sem descartar a hipótese como mera saída utópica, cabe perguntar de que tarefas tal poder se incumbiria. Seu trabalho se restringiria a forçar os agrupamentos mundo afora, com distintas visões de mundo - religiosos ou não -, a estabelecer o diálogo reflexivo, orientado pelo princípio da secularização? Que diferença tal enquadramento teria em relação a antigas formas de dominação entre países e/ou Estados?

A intenção de Habermas ao defender o modelo fraco do político é se distanciar da perspectiva contemporânea de filósofos franceses e italianos - na esteira da tradição de Carl Schmitt, Leo Strauss e Hannah Arendt -, para quem o conceito de político não apenas explica o jogo de forças que operam o conflito no poder e pelo poder (HABERMAS, 2011, p. 16). O filósofo alemão não partilha da tese de que o conceito do político ainda sirva como antídoto para as tendências de despolitização de nossa época. Ele se refere ao fato de nomes como Lefort, Laclau, Agamben, Nancy, entre outros, tomarem como referência a noção de Schmitt e o esquema segundo o qual o político é cindido e atravessado pela oposição e pelo conflito entre amigo e inimigo. Se por um lado essa perspectiva lhes serve para enfatizar o conflito como elemento insubstituível de sociedades como as contemporâneas, por outro, a noção de político que adotam traz implícita a ideia de que para prevalecer no jogo de forças da política na posição do amigo é necessária a eliminação daquela do inimigo. O que não parece correto a Habermas é a prevalência do conflito como dinâmica das relações entre os diferentes que se opõem entre si. 
Parece que reside justamente aqui um ponto cego da tese habermasiana sobre a inserção dos grupos religiosos no "diálogo reflexivo" da esfera pública, sob o manto da secularização. Como obrigar que grupos, religiosos ou não, sejam forçados pelo Estado a mitigar suas visões de mundo em benefício da construção e da efetivação de procedimentos de convivência pública em sintonia com uma sociedade plural, multirreligiosa e secular? O sentido fraco da noção de político de Habermas talvez seja eficiente para repolitizar as relações entre os diferentes grupos na esfera pública sem se deixar cair na armadilha de reduzir todas as relações sociais e políticas à dimensão econômica. Entretanto, sua noção do político nos parece excessivamente amortecida para comportar a tese de que o Estado - envolvido por tradições, instituições arraigadas no tempo - estará comprometido a proceder como um ente neutro e suficientemente confiável, a ponto de convencer os agrupamentos religiosos a harmonizarem sua fé com o privilégio epistemológico das ciências socialmente institucionalizadas, com o primado da laicidade e a com uma moral universalista da sociedade, desligada de visões de mundo setorializadas. Difícil que esse modelo, concebido no contexto de democracias, possa forçar a criação de liames públicos seculares entre grupos religiosos sem que tal impulso se volte contra os próprios princípios democráticos.

\section{REFERÊNCIAS}

ARAÚJO, Luiz B. L. Religião e modernidade em Habermas. São Paulo: Loyola, 1996.

CAMPBELL, M. M. Critical theory and Liberation Theology. A comparision of the initial work of Jürgen Habermas and Gustavo Gutiérrez. Cambridge: Peter Lang Publishing, Inc., 1999.

ESTRADA, Juan Antonio. Por una ética sin teologia. Habermas como filósofo de la religión. Madrid: 2004.

HABERMAS, Jurgen. Discurso filosófico da modernidade. São Paulo: Martins Fontes, 2000.

Direito e democracia: entre facticidade e validade. 2. ed. Rio de Janeiro: Tempo Brasileiro, 1997.

Fé e Saber. São Paulo: Ed. Unesp, 2012.

. Teoria do agir comunicativo. São Paulo: WMF Martins Fontes, 2012b. 2 v.

Mudança estrutural da esfera pública. São Paulo: Ed. Unesp, 2014.

Entre naturalismo e religión. Barcelona: Paidós, 2006. 
"The Political - the Rational meaning of a questionable inheritance of Political Theology". In.: The power of religion in the public sphere. Eds.: MENDIETTA, E.; VANATWERPEN, Jonathan; CALHOUN, Craig. New York: Columbia University Press, 2011.

\& RATZINGER, J. Dialética da secularização: sobre razão e religião. Aparecida: Ideias \& Letras, 2007.

Pensamento pós-metafísico. Rio de Janeiro: Biblioteca Tempo Universitário, 2002.

O futuro da natureza humana: a caminho de uma eugenia liberal? São Paulo: Martins Fontes, 2010.

SIEBENEICHLER, Flávio Beno (org.). Direito, Moral, Política e Religião nas Sociedades Pluralistas. Entre Apel e Habermas. Rio de Janeiro: Tempo Brasileiro, 2006.

TAYLOR, Ch. A Secular Age. Cambridge: Harvard University Press, 2007. 